\title{
10 Teaching History in Belarus: Between Globalization and Authoritarian Confinement, Between Europe and Russia
}

The present Belarusian historiography can be divided into two major schools: Soviet and nationalist. Currently, the Soviet view of history dominates with the support of the political authorities. The education system aims to transmit the official Soviet interpretation of the history of Belarus and to legitimate links with Russia and a specific authoritarian political system. Teaching history in post-Soviet Belarus is extremely complex. The "most Soviet of the USSR's Republics,"1 Belarus has fully adopted the interpretation of both the Soviet and today's political authorities on the fundamental role played by the Soviet period in the construction of the Belarusian historical narrative, memory, national identity, and political system.

Teaching history is a tool for identity building and for geopolitical strategy legitimation. Identity building, referring to history, is built on the frontier between "us" and "the other." For official identity discourse, the Soviet past and the links with Russia are fundamental elements and the educational system aims to transmit the official Soviet interpretation of a sacred role of the Second World War for Belarus. This contribution therefore investigates the discourse of the Second World War in Belarusian society and in school history textbooks, focusing on the following key themes: the Nazi occupation regime, the Holocaust, the collaboration with Nazi Germany, and the partisan movement. The sacralization of the Soviet interpretation of history has an extreme form going even beyond Russia and cements Belarusian nationalism in the 21st century.

\section{The Context of Belarusian History and Historiography}

The history of Belarus, situated at the crossroads of countries and cultural blocs (the Eastern or Eurasian bloc represented by Russia and the Western

1 Valeryi Karbalevitch, “Беларускіфеномен трансфармацыйнага грамадства” [Belarusian phenomenon of a society in transition], Civic Alternative 12 (1999): 12.

๑ Open Access. (C) 2021 Anna Zadora, published by De Gruyter. (cc) BY-NC-ND This work is licensed under the Creative Commons Attribution-NonCommercial-NoDerivatives 4.0 International License. 
bloc represented by Poland), is a history of wars and invasions. Until the 20th century, the lands of present-day Belarus belonged to several state formations such as the Principality of Polotsk, the Grand Duchy of Lithuania, the Polish-Lithuanian Commonwealth, and the Russian Empire. In March 1918, the first Belarusian state was created. Belarus declared independence as the Belarusian People's Republic, succeeded by the Socialist Soviet Republic of Byelorussia (SSRB) in January 1919. Belarus was devastated in the Second World War, following which the republic was considerably redeveloped in the post-war years. In 1945, Belarus became a founding member of the United Nations. The SSRB declared its sovereignty on 27 July 1990, and during the period of the dissolution of the USSR, Belarus declared independence on 25 August 1991.

In order to clarify the conflicts between major history and identity paradigms in Belarus, the general context of current Belarusian historiography should be analyzed. The present Belarusian historiography can be divided into two major discourses: Soviet and nationalist. In this configuration, the Soviet view of history dominates with the support of the political authorities, which have monopolized the majority of social sources. The nationalist interpretation of the history of Belarus is pushed to the margins of the system, and its social impact is extremely limited. The pre-eminence of Soviet historiography over other discourses in Belarus is an exception in the post-Soviet bloc. According to numerous research projects devoted to historical discourse and the teaching of history in the post-Soviet countries, Belarus is the only country that does not describe its relations with Russia and the Soviet period in negative terms. Belarus is the only former Republic of the USSR that experienced a turning point in its historiography in the mid-1990s. If the historical narrative of Belarus at the time of perestroika was formed in opposition to Soviet and Russian imperial discourse, the mid-1990s marked a return to a Soviet-style, Russianorientated, and totalitarian interpretation of history.

\section{Interpretations of History}

In Belarus, the construction of a national identity runs parallel to historiographical construction. The early history of the Belarusian lands dates back to the late 19th century when centrifugal tendencies began to undermine the Russian Empire, sparking the beginnings of interest in this particular province. The first book on the history of the Belarusian land, An Overview of the History of Belarus 
by Vaclau Laustouski, was published in $1910 .^{2}$ The first Belarusian national states - the Belarusian People's Republic and the SSRB - were created in 1918 and 1919, respectively.

In Soviet historiography, the history of Belarus begins only in 1917 and omits the short-lived Belarusian People's Republic, which existed only for some months. The Belarusian people were able to consolidate themselves, and they began their existence as a nation state only through the framework offered by the SSRB. The Belarusian government is a Soviet creation, and the Belarusian people are primarily a Soviet people. The history of Belarus is the history of the SSRB.

In Soviet times, the history of Belarus did not exist, either as an autonomous academic discipline or as a school subject. The first and only school textbook on the history of the SSRB was published in 1960 in Russian and went through 11 editions, remaining the only educational support on the subject until perestroika. The number of books printed was 9,000 copies (for a country with 9,000,000 citizens), which is an indication of the minor place accorded to the history of Belarus as a school discipline during the Soviet period.

Teaching history in the BSSR prescribed the denial of an independent Belarus and an independent Belarusian history. The history of Belarus was merged into Soviet history. Identity politics transmitted through history teaching aimed at the construction of a Soviet identity above all other identities. The following sentences quoted from the only history textbook on Belarus published during the Soviet period are an illustration of the extent to which Belarusian history was viewed as no more than a constituent part of Soviet history, inasmuch as a fundamental tenet of Soviet historiography was its articulation of the Second World War as the central event in the history of the USSR: "From the first days of the occupation, workers in Soviet Belarus began the People's War. Brigades of partisans were created everywhere. Their number increased daily. The organizer and leader of the partisan movement was the Communist Party." 3 The semantic and stylistic construction of the text is revealing. Short sentences and a dogmatic tone meet the objectives of Soviet propaganda: to point out that the information provided by the textbooks is an ultimate and indisputable truth, despite the fact that objective criticisms of these postulates were made by nationalist historians at the time.

2 Vaclau Lastouski, Кароткая гісторыя Беларусі [An Overview of the History of Belarus] (Minsk: Kukhty, 1992).

3 Laurentsi Abetsadarski, The History of the Soviet Socialist Republic of Belarus (Minsk: Public Education, 1968), 121. 
History teaching in the USSR became a propaganda tool underlining the superiority of the Soviet communist model over the Western capitalist model. History as an academic discipline was itself used as an important tool in the construction and legitimization of the Soviet totalitarian state, claiming a specific place for it in world politics. The victory in the Second World War was presented as proof of the superiority of Soviet society over Western society.

\section{Perestroika, Independent Search for Democracy, and European Roots in History}

In the post-Soviet bloc, the period known as perestroika was a crucial moment for the building of states and their national identities. New political parties appeared to challenge the political monopoly of the Communist Party of the USSR, claiming the right of the Soviet Republics to an independent history and an independent future. Since the break-up of the Soviet Union, the majority of postSoviet countries have tended to articulate historical consciousness in opposition to Soviet and Russian interpretations of the past, seeking European roots in their histories.

The writing of history during Soviet times changed completely during perestroika, where history was requisitioned as a legitimizing authority for profound social change, the creation of an independent state in 1990, the establishment of a new socio-political system, and the shaping of a new national identity matrix. Under perestroika, numerous publications appeared in the media relating to the link between education, the teaching of history, and a national renaissance: "Education - the Only Way to a National Renaissance," "Give History Back to the People," or "History Education as a Source of a National Identity." The first school programs on the history of Belarus were inspired by the nationalist party, the National Front program, as was the new Constitution of independent Belarus, which claimed that "the Belarusian people have a long history which can be traced back many centuries." 4 The coat of arms and "nationalist" flag dating back to the era of the Grand Duchy of Lithuania, regarded by Belarusian nationalists as the "Golden Age" of the Belarusian nation, were introduced after the proclamation of independence in 1991.

The gradual gaining of autonomy and the institutionalization of the history of Belarus as an academic discipline and school subject is also linked to perestroika. A decision of the Ministry of Education of 15 September 1986 stated that

4 First Constitution of Independent Belarus, 1991. 
"during the 1986-1987 school year, the history curriculum must be changed, although the creation of new textbooks is not intended for this year." 5 Changes in the history curriculum were reduced to greater attention to the peculiarities of Belarus within the framework of the history of the USSR. The history of Belarus was incorporated into the curriculum of the history of the USSR, and only 27 hours per year were devoted to it. Only in the early 1990s, when the independence of Belarus was proclaimed, did significant qualitative changes take place in the field of writing and teaching history.

The curriculum of the history of Belarus of 1991 emphasizes the fundamental changes in the teaching of history affecting content, methodology, structure, and teaching. For the first time, issues of national consciousness were discussed in the school history curriculum, and new teaching principles such as historical humanism, democracy, and the rejection of dogmatism and stereotypes were introduced. In December 1992, the Minister of Education held a meeting with the most famous historians in the country - Mikhas' Bitch, Ouladzimir Sidartsou, Vital' Famine, and Pavel Loilka - asking them to write school textbooks to be sent to schools in September 1993.

Manuscripts were submitted for printing in March 1993, while the decision to publish the textbooks was taken in December 1992. All the authors wrote books that were more or less acceptable for the school system within three or four months. The lack of a methodological and didactic base for writing history textbooks in Belarus greatly complicated the work of the authors. The historians invited to write the textbooks were academics and researchers rather than secondary school teachers, and they experienced significant difficulties in adapting their styles to the needs of young readers and the requirements of the education system. The historian Henadz Sahanovitch described the restructuring of Belarusian historiography as "a methodological and pedagogical vacuum."

The National Center for Textbooks at the Ministry of Education was the only body responsible for monitoring the manuscripts in 1993. According to the official procedure, the manual first had to be approved by university professors, which would ensure the academic quality of the works. School teachers would then try out and present the results of the use of the new books in the classroom. At the same time as the review process was conducted by professors and teachers, a series of meetings, round tables, lectures, and discussions were organized by the National Center for Textbooks, where different views were exchanged, discussed, and debated.

5 Official Bulletin of the Ministry of Education, September 1986.

6 Henadz Sahanovitch, "Ten years of Belarusian historiography (1991-2000)," Critical Review of Belarusian History 8 (2001): 14. 
The teaching of history and textbook writing during perestroika were the first attempts to move away from the dogmatism of the Soviet period. They encouraged reflection on historical events and personalities and did not contain indisputable dogmas. The authors of the first textbooks put a particular accent on the civic function of the textbooks. The books were supposed to educate patriots and awaken critical thinking skills, which was a novelty, pedagogically speaking, compared with Soviet-era thinking.

\section{Democratization of Society and Condemnation of the Soviet Past}

During perestroika in all the post-Soviet countries, contact with Russia and Russians began to be described in terms of disaster. The communist period is thus frequently described in terms of invasion, occupation, and colonization. For the histories of the post-Soviet countries, Russia played the role of "the other," the "convenient" enemy to which it is possible to attribute all errors and all failures. Russians were classified as invaders, and all territorial divisions, whether unions or annexations, are described in very negative terms.

Pluralism, as one of the most important requirements of a democratic society, was an important element of perestroika history teaching policy. Textbook authors and experts stressed the need to present multiple perspectives on historical events in the textbooks: "The author must give at least two divergent opinions on the facts presented. . . . There are many debatable issues in the science of history, however, the author presents some events as ultimate truths.”7 Pluralistic tendencies are strongly reflected in the books of this period. The introduction that opens Sidartsou and Famine's textbook, published in 1993, clearly states the authors' pedagogical point of view. ${ }^{8}$ Through their manual, the authors aspire "to explain the contradictory process of the development of our society, to help students become aware of the history of Belarus as our history and as part of our everyday lives today." The authors invite young readers to study "the role of historical figures, to reflect on their actions," and "to put themselves in the place of historical characters to understand their motivations." The authors draw attention to the diversity of opinion on the historical facts analyzed in the book: "Different points of view are represented in the textbook. You can

7 Uladzimir Sidartsou, Падручнік Гісторыя Беларусі. 9 [History Textbook Belarus. 9th Grade] (Minsk: Public Education, 1993), 3.

8 Ibid. 
accept them or defend your own opinion; however, you should keep a respectful attitude toward those who have a different opinion from yours. . . . We recommend that students take an active part in debates on controversial issues in order to learn how to defend their points of view." The authors encourage reflection on historical events and personalities, and their book does not contain indisputable dogmas.

The experts who gathered at the National Center for Textbooks at the beginning of the 1990s debated the modalities of revisions of the totalitarian Soviet period, which was a major step toward democratization and openness to democratic values. The condemnation of the Soviet heritage and the search for European roots in Belarusian history was a very important trend in the writing of history textbooks.

During perestroika, the fundamental event of Soviet history - the Second World War - was subject to thorough historical reinterpretation. The myth of the crucial role played by the Communist Party in the victory was debunked, as was the myth of the struggle of the whole people against the Nazis: the whole people did not fight on the side of the Red Army and the partisans. Historians revealed instances of collaborationism and crimes committed by partisans. The Soviet-era glorification of the Second World War was significantly toned down. Stories of victims and of whole communities forgotten by Soviet and Belarusian historiography, such as the Jewish community, were told for the first time in the 1990s.

\section{Search for Links with Europe and the "Europeanization" of History Discourse}

The particular attention paid to the Great Duchy of Lithuania, to which the Belarusian lands belonged between the 12th and 16th centuries, was the result of a search for a valid historical alternative to the idea of the Belarusian nation as a constituent part of the Soviet totalitarian state advanced by Soviet-era historiography. Finding an authentic alternative to the Soviet version of Belarusian history was, however, not a simple matter.

In textbooks published in 1993, particular emphasis was placed on the Grand Duchy of Lithuania and on the wars between the Grand Duchy of Lithuania and Muscovy as historical proof of resistance to Russian domination and links with Europe. Even the titles of the chapters underlined the link between Belarusian and European and world history: "Belarusian Culture in the Context of World 
Civilization," "The Great Patriotic War in the Context of the Second World War," and so on. ${ }^{9}$

It should be noted that the rejection of Soviet totalitarianism and the national revival took extreme forms during this period. "History today still labors under the burden of dogma inherited from previous decades," remarked one expert, although some scholars recognized that the rewriting of history and the rejection of Soviet dogma created a new nationalist dogma and that it was essential to consider the transitional state of historical consciousness in dealing with difficult issues (documents of the National Center for Textbooks). The school textbooks edited in 1993 contained the headings "Historical Fact" and "Historical Document," 10 which prove the intention of the authors to support their narrative with historical documents in order to make them objective.

\section{The Second World War: A Fundamental Event in Belarusian History}

The historical treatment of the Second World War in Belarus, a post-Soviet state with a unique history and a unique treatment of history, is extremely complex. Belarus has fully adopted the interpretation of both the Soviet and today's political authorities on the fundamental role played by this event in the construction of historical narrative, memory, and national identity. The politics of memory, which are the social framework ${ }^{11}$ even for personal memories deployed by the Soviet government, placed the Second World War (known in the former USSR as the Great Patriotic War) at the center of the Belarusian national consciousness as the key event in the development of the Belarusian nation.

In the USSR, victory in the Second World War became a unifying myth for the Soviet people. It was presented as a glorious event where all the people of the USSR joined forces in the fight against Nazism. Heroism, patriotism, and devotion to Soviet ideals under the leadership of the Communist Party led the Soviet people to victory. This victory was presented as an affirmation of the superiority of the Soviet political system in relation to the Western model and was widely used by Soviet propaganda. Neither the Soviet government's responsibility for the war nor the numerous crimes perpetrated against the army and the civilian population before, during, and after the war by the Soviets were revealed.

9 Pavel Loîka, History of Belarus: Textbook for the 7th Grade (Minsk: Public Education, 1993). 10 Ibid.

11 Gérard Namer, Halbwachs and Social Memory (Paris: L'Harmattan, 2002). 
As mentioned above, in Soviet historiography, the history of Belarus begins only in 1917. The history of Belarus is the story of the SSRB. For this reason, the major event in the history of the USSR, victory in the Second World War, is accepted as a fundamental myth in the memory of the Belarusian people, who have few competing myths. Even if alternative myths exist on the margins of society, they are too weak to challenge the main Soviet myth.

\section{Europeanization of the Holocaust Memory and Changes in the Belarusian Interpretation of the Second World War}

Perestroika and the liberalization of the post-Soviet space in the 1980s opened new pages of the history disseminated by the Soviet regime: the Molotov-Ribbentrop Pact, reprisals against Red Army officers, crimes committed by partisans, and the Holocaust. During perestroika, the fundamental Soviet myth of the Second World War was subject to important reinterpretations. The myth of the leading role played by the Communist Party in the victory was debunked, as was the myth of the struggle of the whole people against the Nazis: not everyone fought on the side of the Red Army and the partisans. Historians revealed instances of collaborationism and crimes committed by partisans.

The memory of the Holocaust is a founding historical experience and a unifying memory for Europe. Eastern Europeans had to confront the fact that for Western Europe, the founding historical experience had become the Holocaust, which, for them, was only one part of their history. The newcomers had to tell their own historical experience, unknown to the West, and make it officially part of the European identity. By 1989, the representational modes of the Holocaust memory had become normative in an emerging transnational social space of memory politics, into which Eastern European states entered after the collapse of states' socialist regimes. After 1989, it gradually transformed into a "Europeanized" regime of memory politics in the Western world. ${ }^{12}$

Representation of Holocaust memory in Western Europe served as a model for Eastern European countries, and the canonization of the Holocaust memory became a criterion of Europeanness in order to be considered as a member of the European family by joining the Council of Europe and the European Union. The Holocaust has become a meta-historical, supranationally decontextualized discourse, forming a transnational normative regime of memory. ${ }^{13}$ To recognize

12 Aline Sierp, History, Memory, and Trans-European Identity (London: Routledge, 2014). 13 Michael Rothberg, Multidirectional Memory. Remembering the Holocaust in an Age of Decolonization (Stanford: Stanford University Press, 2009). 
the Holocaust memory and to learn lessons from history became moral obligations in order to prevent human rights violations in Europe, to prevent the atrocities of the past being repeated. The European Union is founded on the indivisible, universal values of human dignity based on the Holocaust memory deprived of its historical context and turned into an ethical inoculation against totalitarian crimes.

The post-Soviet space faced the issue of the Holocaust memory after perestroika and liberalization when the change of political regimes historically coincided with the memory boom in Europe. The Holocaust became a subject of public discussion after decades of Soviet silence on the issue. Belarus, which had a very important Jewish community before the Second World War, found documents proving that more than 600,000 Jews were murdered by the Nazis. The Maly Trostenets extermination camp near Minsk is one of the biggest concentration camps in Europe. ${ }^{14}$

Belarus discovered institutionalized commemoration of the Holocaust in Europe only after the collapse of the Soviet Union, and this helped in recognizing the Holocaust in Belarus. Perestroika was used to claim "Europeanness," and, like other post-Soviet countries, Belarus opted for the European model of the history of the Holocaust.

\section{Re-Sovietization of History Teaching}

The year 1994 witnessed a major shift in the liberalization of Belarusian society. The political forces which came to power in 1994 forged their victory by promising a people in disarray that they would restore the Soviet legacy, fraternal ties with Russia, and the welfare state inherited from the Soviet period. The new government began to use methods inherited from Soviet leaders. A referendum in May 1995 focused on changing state symbols, building a union with Russia, and implementing (?) the Russian language as the state language. The arms and "nationalist" flag dating back to the era of the Grand Duchy of Lithuania, regarded by Belarusian nationalists as the "Golden Age" of the Belarusian nation, were introduced after the proclamation of independence in 1991. After the 1995 referendum, these nationalist symbols were again replaced by those of the Soviet era. The majority of the electorate voted for union with Russia and two state languages: Russian and Belarusian. In 1991, Belarus's Independence Day was established as 27 July in commemoration of the vote for the Declaration of

14 Martin Dean, Collaboration in the Holocaust: Crimes of the Local Police in Belorussia and Ukraine, 1941-44 (London: Palgrave Macmillan, 2000). 
Sovereignty by the Supreme Soviet (the legislative body of SSRs). In 1996, however, Independence Day was changed to 3 July, the day of the liberation of Minsk from the Nazis: further evidence of a return to a Soviet model of writing and interpreting modern Belarusian history.

The referendum institutionalized a return to the Soviet era and to Russianorientated interpretations of history. This legalized Sovietization also affected history writing and teaching and official policies on Belarusian national identity. An edict of the President of Belarus, Alexander Lukashenko, of 16 August 1995 stated: "[G]iven the results of the referendum, it is necessary to replace the books published between 1992 and 1995 with new textbooks." Concerned with defending the Soviet legacy, history textbooks seen by the president as having a nationalistic content were condemned to be replaced by books that better met the aspirations of the new political authorities, who took the Soviet heritage as the basis of their political legitimacy.

The intervention of the political authorities in history teaching and textbook writing provoked heated debates in society. Discussions in the press reflected the negative attitude of teachers and the intelligentsia toward the hardening of control over and manipulation of school history teaching. The round table on history textbooks organized by the Belarusian Historical Review was a response to the decision to remove all textbooks published between 1992 and 1995. Authors and teachers strongly criticized state intervention in textbook rewriting. The author Mikhas' Bitch criticized the authoritarian ban on books edited in 1993: "The history curriculum was openly debated and discussed in 1991 and 1992. Where were the people who are now raising their voices to criticize our textbooks in 1992?"15

\section{Proof of Authoritarian Confinement: Teaching History under Political Censorship}

In the mid-1990s, the creation of the State Commission for the Control of School Literature in the Field of the Humanities and Social Sciences, called into being by a presidential order of 24 August 1995 and answering directly to the presidential administration, marked a new stage in the Belarusian politics of history teaching and textbook writing. This structure responded to the aspiration of the Belarusian political authorities to bring the writing of school history under their

15 Quoted in an unpublished document in the archives of the National Center for Textbooks, Ministry of Education. 
control. Countless mechanisms introduced in the procedure of textbook publishing stifled any attempt to go against the official government conception of history. The purpose of the Commission is to monitor and directly control textbook writing. Thus, the Commission remains the ultimate judge of textbook manuscripts. Before being monitored by the Commission, however, a manuscript must pass many stages of correction and review.

First, a manuscript is read by two experts at the Institute of Education of the Ministry of Education. The experts appointed by the Institute check the didactical and ideological quality of the work. If the manuscript corresponds to the pedagogical requirements of a textbook and is not openly opposed to official ideology, it obtains approval in the first instance. A manuscript can be subjected to a number of criticisms, and the author is obliged to make corrections in response to the experts' objections. The secretariat of the Ministry can send the manuscript back for "improvement" many times until it is accepted by the Commission. The next step is expert analysis and deliberation within the Section of History Textbooks of the Ministry of Education. The Section verifies whether the work corresponds to the official curriculum, the didactical characteristics of the manuscript, and the ideology expounded by the author in the book. The manuscript is submitted to different experts, and if there are points to rework, it is returned to the author(s) for corrections. The officials of the Ministry of Education know which points to "polish" so that the manuscript can be analyzed first by the Presidium of the Academic Council of the Ministry of Education and then by the Commission. Points relating to political history, the Soviet period, and the Second World War are considered to be difficult. After the approval of the Section, the manuscript is submitted to the examination of the Presidium. Its members are appointed by the Ministry of Education, and it is chaired by the Minister of Education. Before deliberation in the Presidium, the manuscript is submitted to the experts of the Commission, and although this does not form part of the official procedure, their opinion carries much weight during deliberations. It is the Presidium that gives the greatest number of negative verdicts to manuscripts. This makes sense, because the next step is the Commission, which makes the final decision on manuscripts, so they must correspond to official ideology by the time they reach this stage. The Commission controls politically important school subjects such as world history, geography, and the literature and history of Belarus. These are the most controversial and politicized academic disciplines, so the political authorities control how they are taught with particular vigilance. The file concerning each manuscript considered by the Commission includes nearly ten expert conclusions, the authors' responses to the corrections made on the basis of objections, and the reports of all the meetings of all the bodies that have analyzed the manuscript. The Commission issues the final verdict. If the manuscript gets the approval of the 
Commission, the Ministry sends the manuscript to the publisher specifying the number of copies to be printed. Such openly authoritarian control over history teaching and textbook writing goes even further than former Soviet methods of control within the educational system.

\section{Forward to the Soviet Past?}

The return to the Soviet interpretation of history resulted in the reselection of topics. Some of them were accentuated, others disappeared. Collaboration during the Second World War is a very problematic issue, which "disappeared" from the present Belarusian historiography. During perestroika, this issue started to be analyzed. It was important to study this phenomenon, the motivation of collaborators who very often were the executioners of Jewish, Roma, and other communities, which is why neighbors became executioners, according to Martin Dean's expression. ${ }^{16}$ In Belarus textbooks edited after 2005, the term "collaboration" is not even mentioned. It is impossible to conduct research on collaborationism in state institutions or to publish research on collaboration in Belarus.

The present Belarusian administration is also aware of the role of education in weaving social ties and building identity: "[H]istory teaching is also a struggle for the minds and souls not only of individuals but also of nations."17 On the one hand, it is imperative to overcome the shortcomings of education within the family in the context of a dramatic decline in the general level of the education of children, to the degree that "textbooks are probably the only books which many children lay their hands on." On the other hand, the school system plays an almost exclusive role in the training of young citizens. Textbooks are the preferred and often the sole instrument of the transmission and legitimization of the particular interpretation of history and narrative of national identity that a political administration aspires to convey.

Within this context, history teaching and school textbooks on history are extremely effective instruments of identity construction. Messages on identity, on "us and the other," can be transmitted and perpetuated across generations through history textbooks distributed to citizens in millions of copies. Their texts, illustrations, and typography can become common references all over a country, guaranteeing a broad, thorough, and continuous impact on the entire population of a territory. The adaptation by several generations of the same

16 Dean, Collaboration in the Holocaust.

17 Alexander Lukashenko, “The Problems of Textbooks," Teachers' Journal 55 (April 2000). 
message, photographs, and historical images transmitted by textbooks can play an important role in legitimizing an official narrative on history and identity within a school system. ${ }^{18}$

Identity discourse transmitted by educational systems becomes a starting point, a basis on which individuals can construct their identity, worldview, and view of the past and history. They begin to assume their belonging to certain groups and their non-belonging to "others" to the point that this perception guides their behavior and becomes a generator and an organizer of practices and opinions. The narrative of the history of a nation as taught in its school system tends to center around certain key events which become markers used in the construction of links between a nation and its past. ${ }^{19}$

In official historiography, alternative historical interpretations are not completely erased but pushed to the margins of the socio-historical narrative. Among the few alternative institutions that can escape the official historiographical dogmas outside the system, there are some institutions in exile that are now located in Vilnius (see below) and the "History Workshop," a German-Belarusian institution in Minsk. The Workshop, located in the territory where the Minsk ghetto was situated, is trying to reveal the "white spots" of the war and of Nazi occupation, including the destiny of the Jewish community and collaboration. ${ }^{20}$ The protection of a diplomatic institution, the German embassy, guarantees it a certain flexibility and freedom of expression.

Soviet historical dogma, and in particular the cornerstone of the Soviet legacy the glorification of the Second World War -, has marginalized other historical interpretations. The pre-eminence of the Soviet interpretation of the war is reflected in partial and biased discourse, full of lacunas and omissions, in school textbooks. Current definitions of Belarusian past and memory cannot be sustainable and will always be weak and susceptible to political manipulation because they are based on partial and lacunar historical references in which the heroic interpretation of the Second World War is incompatible with the victims' narrative. The Holocaust memory was evicted not only from official discourse but even from personal memories. As such, the pre-eminence of the Soviet and Russia-orientated interpretation of history resulted in animosity in analyses of relations with Europe.

18 Hanna Schissler, The Nation, Europe and the World: Textbooks and Curricula in Transition (New York: Berghahn Books, 2005).

19 Mark Bassin and Catriona Kelly, Soviet and Post-Soviet Identities (Cambridge: Cambridge University Press, 2012).

20 Kouz'ma Kozak, German and Collaborationist Loss in Belarus during the Second World War (1941-1944): An Analysis of the Results (Minsk: Logvinov, 2012). 


\section{With Russia and Against Europe}

Animosity between Poles and Belarusians was methodically cultivated over the centuries by the political authorities. The policy of hostility between Belarusians and Poles has been encouraged for centuries by the ruling elite in Belarus, be they Russian, Soviet, or the present-day Belarusian authorities. The goal of this policy is the establishment of a multidimensional border between these peoples in terms of mentality, territory, religion, and language, obscuring the fact that Poles, like Belarusians, are a Slavic people, who are in fact very close to the Belarusians in all these areas. The Belarusian language, for example, is the most "Westernized" of all the Eastern Slavic languages and thus is close to both the Polish and Russian languages. ${ }^{21}$ This artificial and unfounded cultural boundary between Belarus and Poland makes Poles out to be the "worst enemies"22 of Belarusians in all official discourse and political propaganda, which have declared a "war against Poles,"23 evidence of which can be found even in the public sphere and in narratives on education.

If identification is defined as a conscious act of choosing to belong to one particular group rather than to "another" one, ${ }^{24}$ knowledge of national history, which contains a considerable number of questions and answers to issues relating to identity, to common features of the nation and to differences with "others" is the cornerstone of this identification process.

\section{Alternative Historical Interpretations of the Second World War: Marginalized Discourses}

The Soviet view of the history of the Second World War is currently dominant in Belarus; however, it is not the only view. The perestroika period saw a revolution in historiography. In the mid-1980s, history was at the center of social change. The destruction of Soviet dogma led to the search for "new truths," a new concept for the Belarusian nation. The revision of history resulted in a change in social paradigms: what was sacred became profane and vice-versa. Sacred topics in Soviet historiography were reinterpreted and rewritten to match the new nationalist

21 Alexander Boulyko, Typology of Bilinguistic and Multilinguistic Situation in Belarus (Minsk: Belarusian Science, 1999).

22 Leonid Zaiko, National Interests of Belarus (Minsk: Skakoun, 1999).

23 Petar Eberhardt, Demographic Situation in Belarus 1897-1989 (Minsk: Soros Foundation, 1997).

24 Stephen Recher, Self and Nation (London: Sage Publications, 2001). 
narrative. Historians revealed instances of collaborationism and crimes committed by partisans. The heroic and glorious interpretation of the Second World War was significantly reduced. The stories of the victims, of whole communities forgotten by Soviet and Belarusian historiography such as the Jewish community, found their place for the first time in the 1990s.

The historiography of the 1990s highlighted features of the Second World War in the USSR ignored by Soviet historiography: the Molotov-Ribbentrop Pact, the purges in the ranks of the officers of the Red Army on the eve of the war, collaborationism, crimes committed by partisans, and so on. Some researchers, such as the Polish historian Yury Touronak ${ }^{25}$ and the German historian Bernard Chiari $^{26}$ (condemned by the Belarusian authorities), study collaborationism and present it as a mass movement (the only Belarusian Youth Union created by collaborationists on the model of the Hitler Youth counted more than 10,000 members), which goes against official discourse that completely erases this historical fact.

The current socio-political system is making significant efforts to impose the Soviet vision of the Second World War as a holy heroic war of the whole people, the Belarusian nation that defended the home country against Nazi invasion and occupation. Alternative resources are required to defend the alternative version of the war, but these are almost non-existent in Belarus. Only academics who are able to conduct historical research in institutions located outside Belarus, such as the European Humanities University, the Independent Institute of Socio-Economic Research and Political Studies, and the Belarusian Institute for Strategic Studies, all of which are exiled in Vilnius (Lithuania), or those placed under the patronage and protection of foreign bodies (such as the "History Workshop" in Minsk) can afford to challenge the official discourse. In Belarus, in the context of a system that derives its legitimacy from the Soviet legacy, the defense of an alternative interpretation of the war is extremely problematic. Besides costing a great deal, the ability to protest and to defend an alternative interpretation of history is conditioned by how much influence the person protesting is able to exercise. ${ }^{27}$ There are very few historians who feel able to influence the writing and teaching of history, which inhibits protests. Among the few alternative institutions which can escape the official historiographical dogmas outside the system is the already cited "History Workshop" in Minsk, whose central area of research is the Second World War.

25 Touronak 1993.

26 Chiari 1998.

27 Hirschman 1970 


\section{History of the War in the Education System}

The school system is a powerful tool for transmitting collective memory, for building a sense of belonging to a nation state and a national community, and for reinforcing the acceptance of an institutional order by creating a sense of belonging, i.e. an "imagined community." 28 Textbooks are an effective way of transmitting historical narratives concerning national identity. History teaching and history textbooks for schools are extremely powerful and effective tools in shaping national identity in education for many reasons. First of all, the compulsory character of primary and secondary education for children and adolescents must be stressed: no one escapes the educational system of the countries in which they grow up. Secondly, in the Belarusian context, the state educational system has few concurrent agents of education: even the family often delegates its educational function entirely to the school system. Textbooks constitute a powerful force of integration since they "are diffused in hundreds of thousands, taken over several generations even in millions of copies: their texts, illustrations, and typography have been common references . . . for a long time." 29 The role played by history textbooks in the construction of national identity is very important. The content of history textbooks relates directly to questions of national identity. It teaches us to be and think nationally through the interpretation of the events of a particular national history and brings information about the distinction between "us" and "the other" to schoolchildren and young adults in the context of the country in which they are educated.

Many political authorities of different countries and different periods have been aware of the power of history in the formation of the consciousness of citizens, a fact proved by the resolution "On the teaching of history in secondary schools of the USSR" adopted by the Central Committee of the Communist Party of the Soviet Union on 16 May 1934, personally approved by Stalin. This resolution stated that "the teaching of history should no longer refer to abstract patterns of the evolution of sociopolitical formations, but the history of the Soviet state must be presented in a lively and interesting way."30

After the fall of the Soviet Union, historians were asked to debate and justify a new historical discourse and the political project of an independent Belarus, diametrically opposed to the Soviet project. New history textbooks were written on political control in post-Soviet countries at the beginning of the 1990s. Most Soviet

28 Benedict Anderson, Imagined Communities: Reflections on the Origin and Spread of Nationalism (London: Verso, 1983).

29 Marc Ferro, Histoire et ses interprétations (Strasbourg: Conseil de l'Europe, 1997).

30 Stalin 1934. 
Republics conducted a selective inventory of their histories, searching for historical facts and "useful" events which could be mobilized in order to build and legitimate an independent state and national identity. ${ }^{31}$ The highlighting of certain events, such as victory in the Second World War, necessarily entails the treatment of other related issues, such as the responsibility of the Soviet government for the war, the purges on the eve of the war, and the occupation of liberated territories by the Red Army, including the Baltic countries. Such a reduction of history, a "happy eclecticism," ${ }^{32}$ is not only problematic from the standpoint of historical research, but also creates significant political and diplomatic tensions visible in the example of the complex relationship between Russia and the Baltic countries. ${ }^{33}$

School history teaching is now subject to tight political control. The establishment by presidential decree on 24 August 1995 of a State Commission responsible for overseeing the publishing of textbooks in the field of social sciences, reporting directly to the presidential administration, was a milestone in Belarusian historiography. This body responds to the aspirations of the current political masters of Belarus to control the teaching of history in schools. The purpose of the Commission is to monitor and directly control the content of school textbooks.

\section{Soviet Interpretation of the War in Schoolbooks}

To illustrate how the myth of the Great War was created and perpetuated at an academic and scholarly level, it is advisable to refer to the section devoted to the Great Patriotic War in the only textbook of the history of the SSRB published in Belarus during the Soviet period. ${ }^{34}$ The section devoted to the Second World War occupies $6 \%$ of the editorial content of the textbook, proof of the difficulties in interpreting the events of the war in the USSR and of the difficulties to attribute a fundamental role to this event. A major event in the history of the USSR and the SSRB should be developed in depth and deserves more editorial space. The interpretation of the war is only partial. The paragraph begins with the following dogmatic assertion: “On 22 June 1941, Nazi Germany attacked the USSR. Upon the call of the Communist Party, the whole people stood up to fight against the Nazi invaders.” A subparagraph concerning the partisan movement entitled "The partisan war of the whole people" occupies half of the chapter on

31 Bassin 2012.

32 Berger 2007.

33 Lisovskaya Karpov 1999.

34 Abetsadarski, The History of the Soviet Socialist Republic of Belarus. 
the war, and this movement is described in glowing terms. Three elements are highlighted. Firstly, the partisan war was a war of the whole people of Belarus. Secondly, the direction of the movement was provided by the Communist Party. Thirdly, the success of the partisan struggle is emphasized, and no mention of failures or crimes committed by partisans is made. The following sentences quoted from the only textbook of Soviet Belarus illustrate how the history of the Soviet partisans is written about: "From the first days of occupation, workers in Soviet Belarus started the war of the whole people. Brigades of partisans were created everywhere. Their number increased daily. The organizer and leader of the partisan movement was the Communist Party." 35 The semantic and stylistic construction of the text are revealing. The short sentences and dogmatic tone meet the objectives of Soviet propaganda, pointing out that the information provided by the textbooks is an ultimate and indisputable truth, while objective criticisms were leveled by nationalist historians at these postulates of the Soviet interpretation of the war.

An interesting illustration of the continuity of the Soviet tradition, of the social use of collective memory and the importance of the Second World War, is the textbook summarizing the history of Belarus entitled A Gift of the President of Belarus, ${ }^{36}$ which since 2004 has been given to all first-year primary school pupils in Belarus. The book particularly emphasizes the history of the Second World War, both through its text and its illustrations. In the same year, when Belarus celebrated the 60th anniversary of the victory in the Second World War, a special course on this event was introduced for students in the final year of high school and the first year of university. Specific textbooks were published as didactical support for these courses. These textbooks present a Soviet version of the war and scarcely evoke the crimes of Soviet leaders and the complex issue of collaborationism, and reduce the role of the Allies in the victory to a minimum. The Molotov-Ribbentrop Pact and its secret protocol are mentioned, but without explanation: “On 23 August 1939, a German-Soviet agreement of non-aggression was signed (the Molotov-Ribbentrop Pact). At the same time, a secret protocol was signed." 37 In the same textbook, a preface written by the Belarusian president (who has a degree in history) reads:

35 Ibid., 147.

36 Lukashenko 2004.

37 Alexander Kovalenya, Великая Отечественная война советского народа (в контексте Второй мировой войны). 11 [The Great Patriotic War of the Soviet People (In the Context of the Second World War). 11th Grade] (Minsk: Belarusian State University, 2004). 
Some pseudo-academics try to rewrite the history of the Great Patriotic War, diminishing the role of our grandfathers and rehabilitating traitors, collaborators, and slaves of the Nazis. Young people are the main target of these lies. I have confidence in your clear minds and the honesty that allow you to distinguish between truth and falsehood. The living memory of the past will help us to build the future. To know the history of our homeland is a sacred duty of every citizen. Patriotism is the foundation of the courage and heroism with which the Belarusian people has survived all its wars and defended its independence. ${ }^{38}$

The Great Patriotic War is a sacred event in the history of Belarus. Political discourse underlines the heroic role of the Belarusian people, which "together with the peoples of the USSR saved Europe from Nazism." 39 This is a winners' version of events; no mention of the victims of the war is possible. In official rhetoric, the Great Patriotic War is thus presented as a sacred event at the base of Belarusian history, and divergent interpretations are erased.

\section{The Holocaust in Belarusian Textbooks}

Another important argument of the continuity of the Soviet tradition of the Second World War's interpretation in history textbooks is the representation of the Holocaust. In Soviet historiography and textbooks, "Holocaust" is an absent term. Now, it is not possible to avoid the events related to the Holocaust completely, but their interpretation is partial and distorted.

Four textbooks on the history of Belarus treating the Holocaust are analyzed here: Evguenii Novik's История Беларуси 1917-1945. 10 [History of Belarus 1917-1945. 10th grade], Ouladzimir Sidartsou's Падручнік Гісторыя Беларусі. 9 [History of Belarus. 9th grade], Petar Petrykau's Гісторыя Беларусі. 11 [History of Belarus. 11th grade], and Alexander Kovalenya's Великая Отечественная война советского народа (в контексте Второй мировой войны) [The Great Patriotic War of the Soviet People (In the Context of the Second World War). 11th grade]. ${ }^{40}$

38 Alexander Lukashanko, "Preface," in Alexander Kovalenya, Великая Отечественная война советского народа (в контексте Второй мировой войны). 11 [The Great Patriotic War of the Soviet People (In the Context of the Second World War). 11th Grade] (Minsk: Belarusian State University, 2004).

39 Alexander Lukashenko, The Historical Choice of Belarus (Minsk: State University Press, 2003).

40 Evguenii Novik, История Беларуси 1917-1945. 10 [History of Belarus 1917-1945. 10th Grade] (Minsk: Public Education); Sidartsou, History Textbook Belarus; Petar Petrykau, 
The official curriculum mentions: "The 'West' plan the Nazi occupation regime. The genocide." No clarification is given by the curriculum on the teaching of the reasons for the Holocaust, or its consequences, or its remembrance. The program of the special course on the Great Patriotic War does not mention the term "Holocaust." Concerning the time allocated to teaching and learning about the Holocaust in schools, 11 hours are devoted to the topic "The BSSR during WWII and the Great Patriotic War" for the 11th grade, of which two hours are given to the occupation regime and the genocide. (Within the framework of the special course on the Second World War and the Great Patriotic War, two hours are devoted to the occupation regime.)

The Belarusian textbooks present the Holocaust within the context of the Second World War and, more specifically, in the context of occupation during the "Great Patriotic War." Some textbooks present the Holocaust in the framework of chapters entitled "Struggle against Nazi aggression," "The regime of occupation," and "A policy of genocide and violence," offering brief chronologies of the event in some sentences or paragraphs. The average number of pages devoted to the occupation regime varies from one to three in books of approximately 200 pages.

The terms used to describe Holocaust are "genocide," "mass murder," and "planned extermination of the Soviet people." The only Belarusian textbook to use the term "Holocaust" is Kovalenya's for the special course on the Second World War in the following sentence: "The Holocaust is the extermination of the Jewish population of Europe by the Nazis during WWII." ${ }^{\circ 1}$ Other textbooks offer the following vague explanations: "According to the plan of the 'West,' Jewish people, communists, and representatives of Soviet authority were all condemned to total extermination ... '[a] racially harmful' part of the population - Jewish people, gypsies, and the physically and mentally ill - were condemned to extermination in a particularly cruel manner." The extermination of Jewish people in Belarus is treated as part of the extermination of Soviet people.

The books do focus on military warfare and political events but without giving space to individual experiences or testimonies. The lives of Jewish people before and after the Second World War in Europe are not depicted. No dates are ascribed to the Holocaust to mark the main occurrences or its beginning and end. This event is not linked to earlier events of the 18th or 19th centuries. The genocide of the Jewish people is treated within the context of the Second World

Гісторыя Беларусі. 11 [History of Belarus. 11th Grade] (Minsk: Public Education, 2002); Kovalenya, The Great Patriotic War.

41 Kovalenya, The Great Patriotic War, 36. 
War, but without a relevant explanation and without a clear indication of the relationship between the Holocaust and the Second World War. The explanation of the genocide of the Jewish people is very short and so disconnected from the general context that it is impossible even to begin to understand the Holocaust as a phenomenon based on the text in the textbooks.

The representation of the Holocaust in Belarusian textbooks does not establish the links with the European context. Though Kavalenya's textbook's maps depict the sites of camps on a European scale and show the sites of ghettos and extermination camps in Belarus and the Soviet Union, the textbooks do not establish a spatial link with Europe or the Soviet Union. The textbook for the special course on Second World War history only mentions the Maly Trostenets camp near Minsk, as well as Auschwitz, Majdanek, and Treblinka, without any reference to the Holocaust as a European phenomenon. In this textbook, and in spite of the maps of Europe showing the sites of camps, the text does not explain the geopolitical dimensions of the Holocaust, but rather presents it only insofar as it affected Belarus.

Concerning the names of the protagonists, the emphasis is put on Soviet people in the abstract, while Jewish victims, Gypsies, and "racially harmful" parts of the population, including "the physically and mentally ill," are only mentioned in passing. The main focus of all textbooks is a factual and impersonal account of the extermination, detailing the number of camps, people murdered, villages destroyed, etc. There is no portrayal either of the victims or of the perpetrators. Novik's textbook names the victims as "people," without any reference to the categories defined by the National Socialist regime. There are no distinctions between the treatment of various victim groups, such that the murder of Jews in Belarus in Sidartsou's textbook, for example, is presented within a passage about the murder of Soviet people; likewise, different victim groups are lumped together indiscriminately in Petrykau's textbook, that is, as "people who perished" and as "all who were condemned to total extermination." All books list the numbers of "people" killed in the Maly Trostenets camp, and all books list the numbers of "people" or "Jewish people" killed in the Minsk ghetto. Perpetrators are referred to as "Hitler's soldiers," "Nazis," "collaborators," "occupiers," "Germans," and "aggressors." None of the textbooks contain images of Hitler in connection with the Holocaust, nor do they address the role of the Allies, bystanders, or individual stories. The motivations of the defined individual persecutors (e.g. a desire for revenge, a sense of duty, peer pressure, the wish for power, a sense of justice, fear, etc.) are not provided. No space is devoted to ambivalence and human error, refusal or heroism, beyond the polarized depictions of victims and perpetrators. A characteristic of all the books covered in the survey is a general silence regarding 
local people who participated in extermination operations or people who risked their lives to save members of the Jewish population during the Second World War in Belarus. There are numerous instances of such acts. As of 2014, Yad Vashem listed 601 names of Belarusians among the Righteous Among the Nations. However, none of the books mention either helpers, rescuers, or local people who participated in or abetted killings or collaborated with perpetrators of the Holocaust in Belarus. The Belarusian national narrative is consequently relatively limited with regard to the historical perspectives that are offered to pupils and thereby the next generation. As highlighted by Peter Carrier et al., in contrast, "partisan resisters feature prominently in all books," and the fate of individual women is indicated visually in Kovalenya's textbook via an image of a child next to his dead mother; although the child is named as Tolia Markovets, no information concerning the place and date of, or the reason for, the killing is provided. ${ }^{42}$ The partisan-maquis movement is dealt with in detail, as befits its quasi-'sacred' status within Belarusian historiography and national politics of historical memory. The impersonal style explains the very small number of pronouns used. There are only some rare instances of personal pronouns in all the textbooks. Passive constructions dominate the text, such as: "The territory of Belarus was covered with a network of concentration camps," 43 "In the occupied territory a 'new order' was established, a regime based on genocide, mass extermination, and the theft of national resources," 44 and "The extermination was carried out." ${ }^{45}$ None of the textbooks use superlative or emotive terms. The sections dealing with the Holocaust do not reflect a general decline (of morality, human rights, or modernity), nor do they include elements of hope or redemption. No comparisons are made between the Holocaust and similar events in other parts of the world (e.g. genocides, the effects of dictatorships).

The extermination of the Jewish people, without the term "Holocaust," is depicted in a factual manner: the numbers of instances of mass extermination and of concentration camps and ghettos are given. The presentations of the Holocaust are not comprehensive or historical but consist of brief statements outlining facts of the event, such as the numbers of camps and ghettos and the identity of selectively chosen perpetrators and victims. These statements are generally short and disconnected from the context of the Second World War and do not constitute explanations of the event. The aims of perpetrators are described in the context of the Generalplan Ost (General plan for the East),

42 Peter Carrier et al., The International Status of Education about the Holocaust: A Global Mapping of Textbooks and Curricula (Braunschweig: UNESCO, 2015), 85.

43 Novik, History of Belarus.

44 Sidartsou, History Textbook Belarus.

45 Petrykau, History of Belarus. 
according to Novik, in which $75 \%$ of Belarusians were to be killed or displaced and $25 \%$ of them used for forced labor, while all Jews and "Gypsies" were to be killed. Sidartou describes the aims of the perpetrators as a "new order . . . based on genocide, mass extermination, and the theft of national resources." The causes of and motives for the Holocaust are not explained, although references to "racially harmful" people in Kovalenya's textbook suggest that causes of the event were rooted in ideological motivations.

The average number of illustrations and documents relating to the Holocaust is three in all analyzed textbooks. Beyond administrative documents, including a letter from the General Commissar of Belarus about the killing of Jews in Novik's textbook and an official order concerning the "Jewish district" of Minsk in Kovalenya's textbook, the textbooks contain few iconic images of the Holocaust, such as the camp badges used to identify people from Eastern Europe or the entrance to Auschwitz (in Sidartsou's textbook). Historiographical or commemorative issues are not addressed.

All authors adopt a neutral voice, providing a single authorial point of view with minimal indications of other points of view. This imbalance is reflected in the fact that $90-100 \%$ of sections about the Holocaust are devoted to authors' texts alongside up to $10 \%$ of documents or maps, while Kovalenya's textbook devotes $60 \%$ of the available space to documents alongside $40 \%$ of text. The authors offer no meta-historical reflection about historical methods or commemorative uses of the Holocaust. By confining the scope of the narratives to the period of the war and to Belarusian territory, they likewise provide fatalistic moral accounts with no reference to the long-term causes or consequences of the Holocaust. The references to "occupiers" reveal a narrative bias toward a national Belarusian standpoint. The narrative is also not organized according to specific themes or problems (such as morality, politics, or psychology) but is reduced to a catalog of facts.

Novik's textbook requires pupils to explain the meaning of "genocide" in relation to a document and secondary literature. Sidartsou's and Petrykau's textbooks each contain one question about the Holocaust requesting pupils to define the characteristics of the "occupying regime." In Novik's textbook, there is one question asking pupils to explain the Generalplan Ost and one relating to the genocide requiring an explanation of the term together with a description of the phenomenon through an analysis of the document in the textbook and complementary literature. Sidartsou's textbook contains only one question related to the genocide, asking pupils for a characterization of the occupation regime using the map of concentration camps. Petrykau's textbook has one question related to the extermination policy, asking pupils for a characterization of the occupying regime. Kovalenya's textbook requires an explanation for the forced 
dislocation of Jews from Minsk and a definition of the characteristics of the genocide in occupied Belarus. The authors' general didactic approach to the Holocaust therefore offers pupils the opportunity to learn of the Holocaust, but little about or from it.

The textbooks present the Holocaust strictly in the context of local or national Belarusian history, in line with the stipulation for Belarusian curricula that teaching about the Holocaust should take place within the context of the history of Belarus and, more specifically, of the "Great Patriotic War." Repeated references to the occupation of Belorussia in the context of the Holocaust suggest that the Holocaust primarily involved a violation of Belarusian territory. Sidartsou, for example, refers to "the occupied territory" and Novik to that fact that "[t]he territory of Belarus was covered with a network of concentration camps," while exercises in Petrykau's and Kovalenya's textbooks ask pupils to describe the Holocaust from the point of view of members of an occupied country. This local vision of the event is reinforced by further references to camps, above all to the Maly Trostenets camp and the Minsk ghetto in Belarus; to the equal status accorded to Jews, "Gypsies," and Belarussian nationals as victims of the Generalplan Ost in Novik's textbook; and by reproducing images of badges worn by Eastern Europeans and Belarussians in camps in Sidartsou's textbook. There is a tendency to nationalize victimhood. The numbers of Jewish victims listed in all books refer only to those who were killed in either Maly Trostenets or the Minsk ghetto, although Novik does not name the categories of victims and Sidartsou focuses primarily on Soviet victims. By naming the perpetrators as "Hitler's soldiers," "Nazis," "collaborators," "occupiers," “Germans," and "aggressors," the textbooks testify to a further tendency to externalize perpetration, which is not embodied in the person of Hitler but in multiple, largely national, German agents.

\section{Conclusion}

The recent Belarusian historiography and identity matrix is divided into two competing interpretations of history and two approaches to producing historical narratives: nationalist and Soviet. Each of these approaches mobilizes and articulates facts and historical events in order to legitimize a political discourse and a narrative of historical identity. In current Belarusian historiography, a clear imbalance exists between the historical narratives in favor of the Soviet doctrinal and dogmatic narrative. The history of the 20th century witnessed the misuse of history in the USSR to justify crimes, exterminations, and reprisals. The use of nationalist history in different contexts also showed the dangers of 
an aggressive nationalism. A single perfect historical narrative, a unique historical consciousness, a single way of interpreting the past cannot exist, but this narrative must be plural, open, without dogma, and without monopoly, which is not the case in Belarus today.

The nationalist discourse on historical consciousness and national identity is condemned to obscurity due to the lack of opportunity for its transmission and legitimization. The only model for historical consciousness and national identity for Belarusians is the Soviet model defended and promoted by the authorities. The alternative project promoted by nationalist forces is also a negative project, incapable of becoming a reference for national unity. The problem of the lack of a regular and stable point of reference is the absence of a necessary consensus on national identity. Soviet historical dogma, and in particular the cornerstone of the Soviet legacy - the glorification of the Second World War -, has marginalized other historical interpretations. The pre-eminence of the Soviet interpretation of the war is reflected in partial and biased discourse, full of lacunas, on the Second World War in identity discourse and school textbooks. Thus, ideas of Belarusian national identity are once again based exclusively on negative and destructive references to war. Remembrance of the past and historical discourse, where it relates to national identity, should have an open, peaceful, pluralistic, and discursive basis and should transcend controversial issues like wars and conflicts. Current definitions of Belarusian identity cannot be sustainable and will always be weak and susceptible to political manipulation because they are based on destructive historical references.

The acceptance of official discourse on historical memory is due to the marginalization of other discourses. The formative influence of the politics of memory is powerful if society remembers the past in a similar but not identical way, generating an idea of historical truth and reinforcing belief in the version of history commemorated. The current Belarusian political authorities aspire to disseminate a Soviet, Russia-orientated version of Belarusian history and national identity in the interest of justifying their own legitimacy. In order to do so, they need an interpretation that can be accepted without discussion by the population. In this specific context, any interpretation of national identity must be as simplistic and dogmatic as possible. The result of mixing Soviet and nationalist references are weak and contradictory discourses and textbooks, unfit to be consistent and stable referents for the construction of national identity, for fostering a sense of belonging to a national community, or for justifying the place of a nation in the global system. This is extremely important for Belarus, as its Democracy Index is continuously ranked the lowest in Europe. It is the only country on the European continent not to be a part of the Council of Europe and the only one that still implements the death penalty. 


\section{Works Cited}

Abetsadarski, Laurentsi. The History of the Soviet Socialist Republic of Belarus. Minsk: Public Education, 1968.

Anderson, Benedict. Imagined Communities: Reflections on the Origin and Spread of Nationalism. London: Verso, 1983.

Bassin, Mark and Catriona Kelly. Soviet and Post-Soviet Identities. Cambridge: Cambridge University Press, 2012.

Boulyko, Alexander. Typology of Bilinguistic and Multilinguistic Situation in Belarus. Minsk: Belarusian Science, 1999.

Carrier, Peter et al. The International Status of Education about the Holocaust: A Global Mapping of Textbooks and Curricula. Braunschweig: UNESCO, 2015.

Dean, Martin. Collaboration in the Holocaust: Crimes of the Local Police in Belorussia and Ukraine, 1941-44. London: Palgrave Macmillan, 2000.

Eberhardt, Petar. Demographic Situation in Belarus 1897-1989. Minsk: Soros Foundation, 1997.

Ferro, Marc. Histoire et ses interpretations. Strasbourg: Conseil de l'Europe, 1997.

Karbalevitch, Valeryi. “Беларускіфеномен трансфармацыйнага грамадства” [Belarusian phenomenon of a society in transition]. Civic Alternative 12 (1999).

Kovalenya, Alexander. Великая Отечественная война советского народа (в контексте Второй мировой войны). 11 [The Great Patriotic War of the Soviet People (in the context of the Second World War). 11th Grade]. Minsk: Belarusian State University, 2004.

Kozak, Kouz'ma. German and Collaborationist Loss in Belarus during the Second World War (1941-1944): An Analysis of the Results. Minsk: Logvinov, 2012.

Lastouski, Vaclau. Кароткая гісторыя Беларусі [An Overview of the History of Belarus]. Minsk: Kukhty, 1992.

Lindner, Rainer. Historiker und Herrschaft. Nationsbuildung und Geschichtspolitik in Weißrußland im 19. und 20. Jahrhundert. Munich: R. Oldenbourg Verlag, 1999.

Loïka, Pavel. History of Belarus: Textbook for the 7th Grade. Minsk: Public Education, 1993. Lukashenko, Alexander. The Historical Choice of Belarus. Minsk: State University Press, 2003.

Lukashanko, Alexander. "Preface." In Alexander Kovalenya, Великая Отечественная война советского народа (в контексте Второй мировой войны). 11 [The Great Patriotic War of the Soviet People (In the Context of the Second World War). 11th Grade]. Minsk: Belarusian State University, 2004.

Lukashenko, Alexander. “The problems of textbooks.” Teachers' Journal 55 (April 2000).

Namer, Gérard. Halbwachs and Social Memory. Paris: L'Harmattan, 2002.

Novik, Evguenii. История Беларуси 1917-1945. 10 [History of Belarus 1917-1945. 10th Grade]. Minsk: Public Education, 2012.

Petrykau, Petar. Гісторыя Беларусі. 11 [History of Belarus. 11th Grade]. Minsk: Public Education, 2002.

Recher, Stephen. Self and Nation. London: Sage Publications, 2001.

Rothberg, Michael. Multidirectional Memory. Remembering the Holocaust in an Age of Decolonization. Stanford: Stanford University Press, 2009.

Sahanovitch, Henadz. "Ten years of Belarusian historiography (1991-2000)." Critical Review of Belarusian History 8 (2001). 
Schissler, Hanna. The Nation, Europe and the World: Textbooks and Curricula in Transition. New York: Berghahn Books, 2005.

Sidartsou, Uladzimir. Падручнік Гісторыя Беларусі. 9 [History Textbook Belarus. 9th Grade]. Minsk: Public Education, 1993.

Sierp, Aline. History, Memory, and Trans-European Identity. London: Routledge, 2014. Trechtchenok, Yakov. The History of Belarus. Mogilev: University of Mogilev Press, 2005.

Zaiko, Leonid. National Interests of Belarus. Minsk: Skakoun, 1999. 